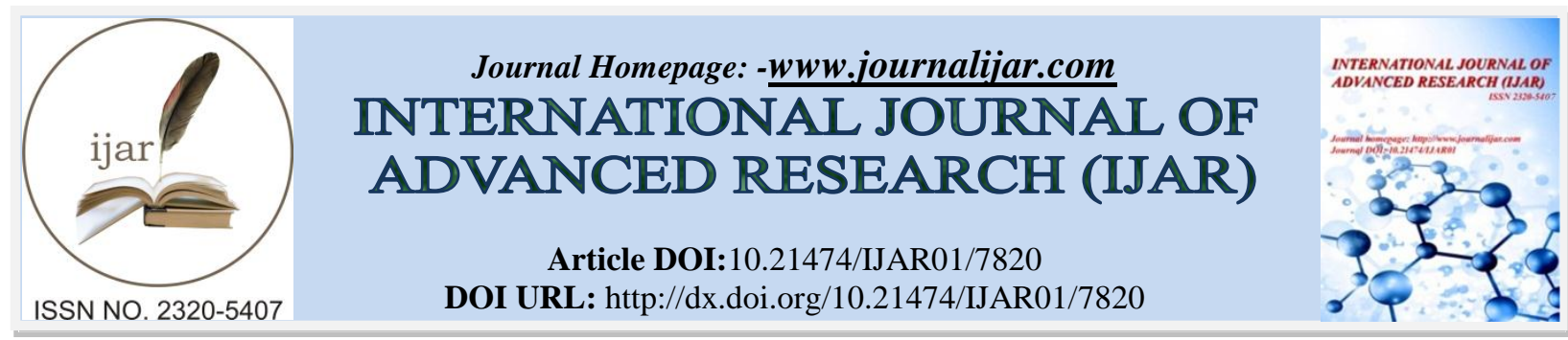

RESEARCH ARTICLE

\title{
CLINICAL STUDY OF ASSOCIATION BETWEEN THE SERUM SODIUM LEVEL AND SEVERITY OF COMPLICATIONS IN LIVER CIRRHOSIS AT KANYAKUMARI GOVERNMENT MEDICAL COLLEGE.
}

\begin{abstract}
Amalan Christudhas V ${ }^{1}$, Ilakkiya Venu ${ }^{2}$, Suhas Raj Sivakumar ${ }^{2}$ and Silambarasan ${ }^{2}$.
1. Assistant professor, Department of General Medicine, Kanyakumari Government Medical College.

2. Postgraduate in General Medicine, Kanyakumari Government Medical College.
\end{abstract}

\section{Manuscript Info}

Manuscript History

Received: 6 August 2018

Final Accepted: 8 September 2018

Published: October 2018

Keywords:

Hyponatremia, Liver cirrhosis.

\section{Abstract}

Background: Cirrhosis is defined histopathologically and has variety of clinical manifestations and complications, some of which can be lifethreatening..Dilutionalhyponatremia associated with liver cirrhosis is caused by impaired free water clearance. The aim of this study was to evaluate the association between the serum sodium level and the severity of complications in liver cirrhosis .

Methods:This study was conducted in Kanyakumari Government Medical College in the department of general medicine . 200 patients were included in the study over a period from August 2017 - August 2018 for a period of 1 year. Data of inpatients with cirrhotic complications were collected retrospectively. The serum sodium level and severity of complications of 200 inpatients were analysed.

Results: The prevalence of dilutionalhyponatremia, classified as serum sodium concentrations of $>135 \mathrm{mmol} / \mathrm{L}, 131-135 \mathrm{mmol} / \mathrm{L}$, and $\leq 130$ $\mathrm{mmol} / \mathrm{L}$, were $44 \%, 24 \%$, and $32 \%$, respectively. The serum sodium level was strongly associated with the severity of liver function impairment as assessed by Child-Pugh and MELD scores $(\mathrm{p}<0.0001)$. Even a mild hyponatremia with a serum sodium concentration of 131$135 \mathrm{mmol} / \mathrm{L}$ was associated with severe complications.

Conclusion: Hyponatremia is more common in liver cirrhosis and low serum sodium levels are associated with complications such as hepatic encephalopathy ,hepatorenal syndrome, spontaneous bacterial peritonitis and GI bleeding. Lower serum sodium levels were associated with increased MELD CPS score and mortality indicating the inverse relationship between serum sodium levels and severity of the disease.

Copy Right, IJAR, 2018,. All rights reserved.

\section{Introduction:-}

Cirrhosis is defined anatomically as a diffuse process with fibrosis and nodule formation. It is the end result of fibrogenesis that occurs with chronic liver injury. Decompensated liver disease associated with disturbances in water homeostasis which leads to dysnatremia. Excess water in relation to sodium results in hyponatremia. Disturbances in total body water regulation leads to reduced clearance of solute free water \& the consequent inability to match the urine output to the amount of water intake, leads to dilutionalhyponatremia. 


\section{Methods:-}

Subjects:-

Patients who were hospitalized with complications due to liver cirrhosis during a 1 year period between 2017 to 2018 at Kanyakumari government medical college .

\section{Study Design:-}

Based on the serum sodium concentration measured at the time of admission, patients were divided into three groups serum sodium < $130 \mathrm{mmol} / \mathrm{l}$, serum sodium between $131-135 \mathrm{mmol} / \mathrm{l}$, serum sodium $>136 \mathrm{mmol} / \mathrm{l}$.

\section{Basal characteristics of the patients:-}

\begin{tabular}{|l|l|}
\hline CHARACTERISTICS & VALUE \\
\hline Gender (m/f) & $153 / 47$ \\
\hline & \\
\hline Age , yr (mean +/- SD ) & $55.8+/-11.6$ \\
\hline & \\
\hline Cause of cirrhosis & $\mathrm{N}(\%)$ \\
\hline Alcohol & $117(58.5 \%)$ \\
\hline HBV & $53(26.5 \%)$ \\
\hline HCV & $15(7.5 \%)$ \\
\hline Others & $13(6.5 \%)$ \\
\hline
\end{tabular}

\section{SEX DISTRIBUTION}

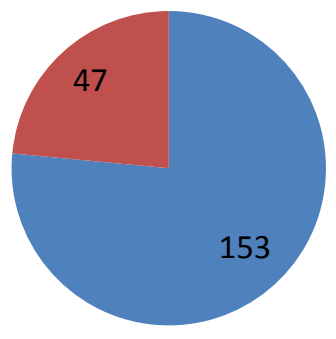

MALE

FEMALE 

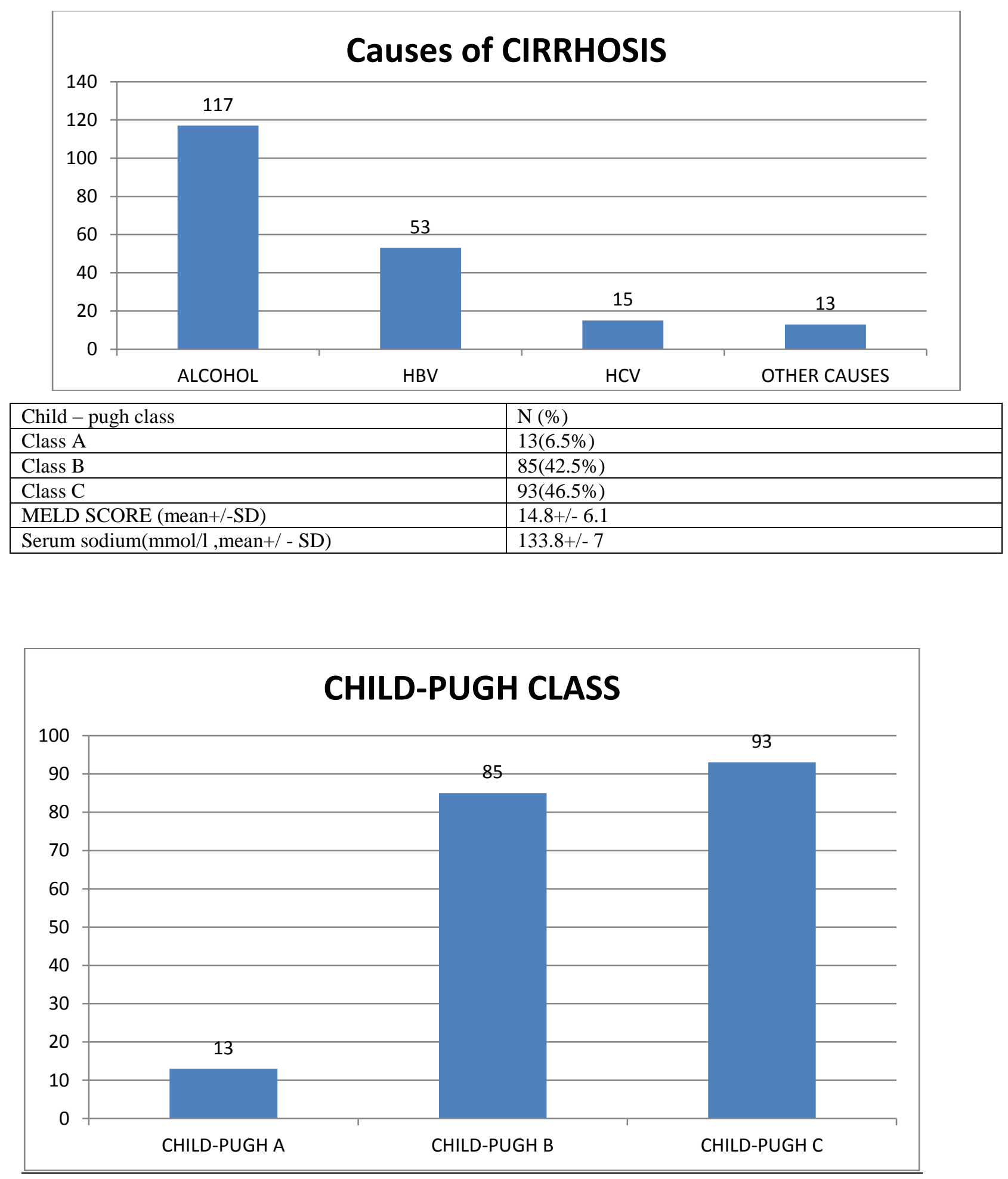

\begin{tabular}{|l|l|}
\hline Complications & \\
\hline Ascites & $156(78.0)$ \\
\hline Hepatic encephalopathy & $65(32.5)$ \\
\hline Spontaneous bacterial peritonitis & $47(23.5)$ \\
\hline Hepatic hydrothorax & $27(13.5 \%)$ \\
\hline
\end{tabular}




\begin{tabular}{|l|l|}
\hline Infection & $16(8 \%)$ \\
\hline Hepatorenal syndrome & $6(3 \%)$ \\
\hline Esophageal varix & $165(82.5 \%)$ \\
\hline Gastric varix & $51(25.5 \%)$ \\
\hline Variceal bleeding & $58(29 \%)$ \\
\hline Intractable ascites & $11(5.5 \%)$ \\
\hline
\end{tabular}

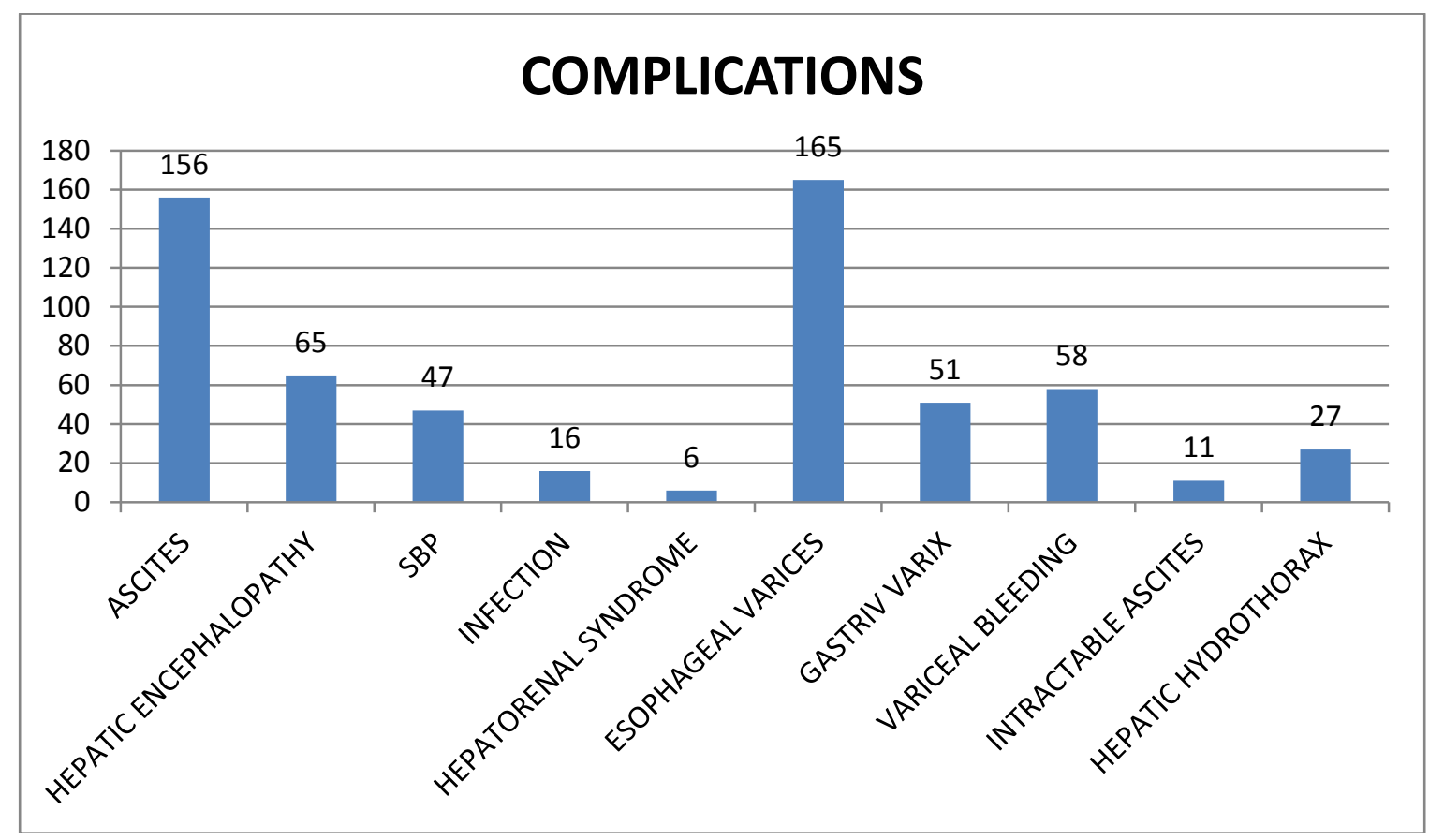

\section{Statistical analysis:}

Statistical analysis was performed using SAS. Statistical methods included the Chi-square test and ANOVA. A p value $<0.05$ was considered statistically significant.

\section{Patient characteristics}

In the current study, we analyzed 200 inpatients with liver cirrhosis who were hospitalized with complications such as simple ascites, spontaneous bacterial peritonitis, intractable ascites, hepatorenal syndrome, hepatic encephalopathy, variceal bleeding, hepatic hydrothorax, and infection. Patients in our series had a mean age of55.8 \pm 11.6 years (range, 29-82 years) and consisted of 153 men (76.5\%) and 47 women (23.5\%).

\section{Liver function and concurrent complications based on serum sodium concentration}

Based on the serum sodium concentration at the time of admission, patients were assigned to three groups: serum sodium $\leq 130 \mathrm{mmol} / \mathrm{L}(\mathrm{n}=64)$ serum sodium between 131 and $135 \mathrm{mmol} / \mathrm{L}(\mathrm{n}=48)$ and serum sodium $\geq 136 \mathrm{mmol} / \mathrm{L}$ $(\mathrm{n}=88)$

Characteristics of patients according to serum sodium concentration

\begin{tabular}{|l|l|l|l|}
\hline Characteristics & $\begin{array}{l}</-130 \mathrm{mmol} / \mathrm{l} \\
(\mathrm{n}=64)\end{array}$ & $\begin{array}{l}131-135 \mathrm{mmol} / \mathrm{l} \\
(\mathrm{n}=48)\end{array}$ & $\begin{array}{l}>/-136 \mathrm{mmol} / \mathrm{l} \\
(\mathrm{n}=88)\end{array}$ \\
\hline MALE & 47 & 37 & 69 \\
\hline FEMALE & 17 & 11 & 19 \\
\hline & & & \\
\hline ETIOLOGY & & & \\
\hline ALCOHOL & 37 & 22 & 42 \\
\hline HBV & 20 & 19 & 36 \\
\hline
\end{tabular}




\begin{tabular}{|l|l|l|l|}
\hline HCV & 4 & 3 & 4 \\
\hline Non B / Non C & 3 & 4 & 6 \\
\hline & & & \\
\hline CHILD PUGH CLASS & & & 7 \\
\hline CLASS A & 5 & 4 & 53 \\
\hline CLASS B & 17 & 19 & 28 \\
\hline CLASS C & 42 & 25 & \\
\hline
\end{tabular}

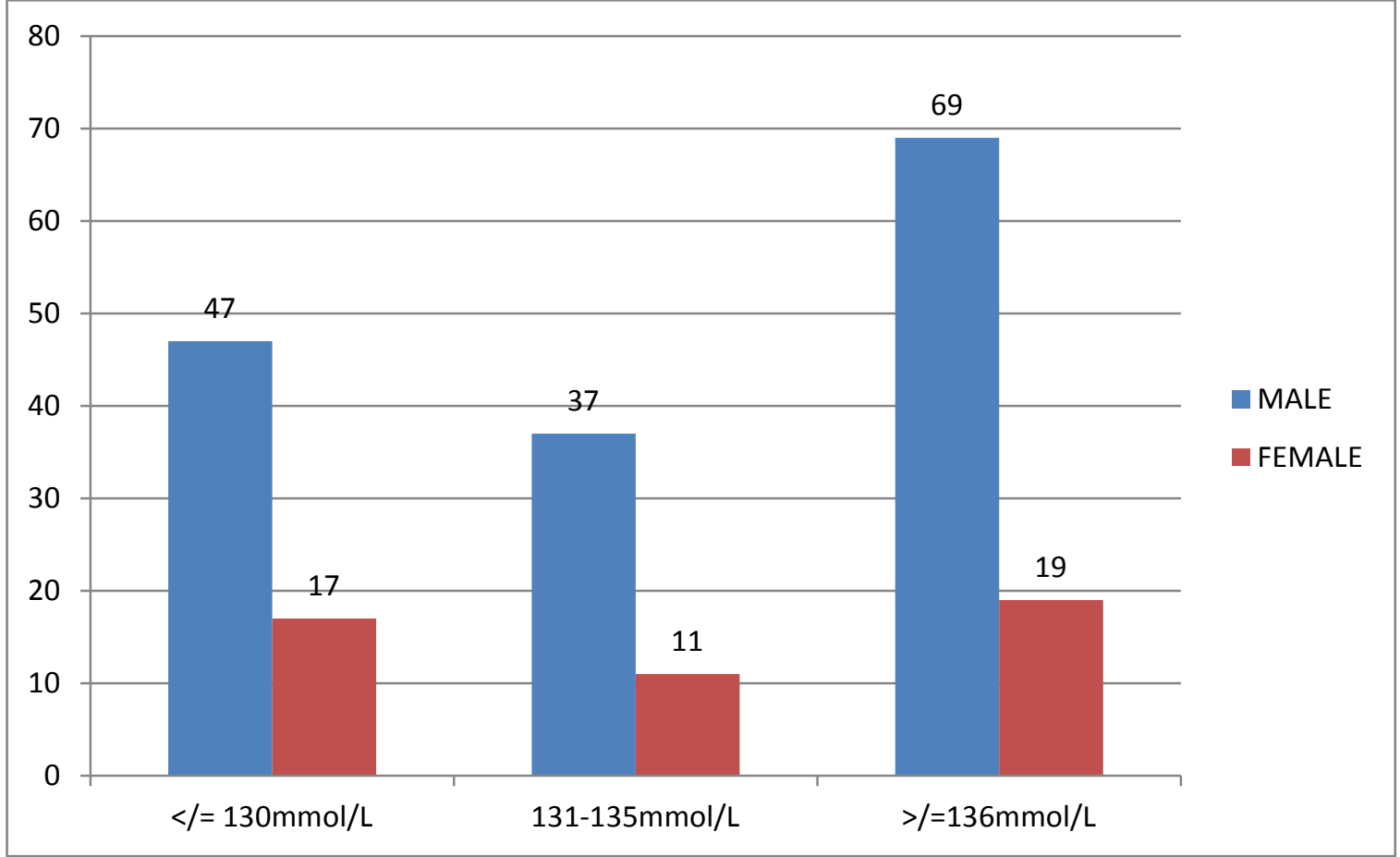

Frequency of complications by serum sodium concentration:

\begin{tabular}{|l|l|l|l|}
\hline COMPLICATION & $\begin{array}{l}</-\mathbf{- 1 3 0} \mathbf{~ m m o l} / \mathbf{l} \\
(\mathbf{n = 6 4})\end{array}$ & $\begin{array}{l}\mathbf{1 3 1 - 1 3 5 m m o l} / \mathbf{l} \\
(\mathbf{n = 4 8})\end{array}$ & $\begin{array}{l}>/-\mathbf{- 1 3 6} \\
(\mathbf{n}=\mathbf{8 8})\end{array}$ \\
\hline & & & $\mathbf{m m o l} / \mathbf{l}$ \\
\hline Ascites & 56 & 42 & 64 \\
\hline SBP & 21 & 15 & 15 \\
\hline Intractable ascites & 6 & 1 & 3 \\
\hline HRS & 3 & 2 & 3 \\
\hline H.Encephalopathy & 28 & 17 & 21 \\
\hline Varix bleeding & 16 & 13 & 29 \\
\hline H.hydrothorax & 14 & 7 & 4 \\
\hline Infection & 5 & 2 & 7 \\
\hline Esophageal varix & 52 & 37 & 72 \\
\hline Gastric varix & 11 & 8 & 27 \\
\hline
\end{tabular}




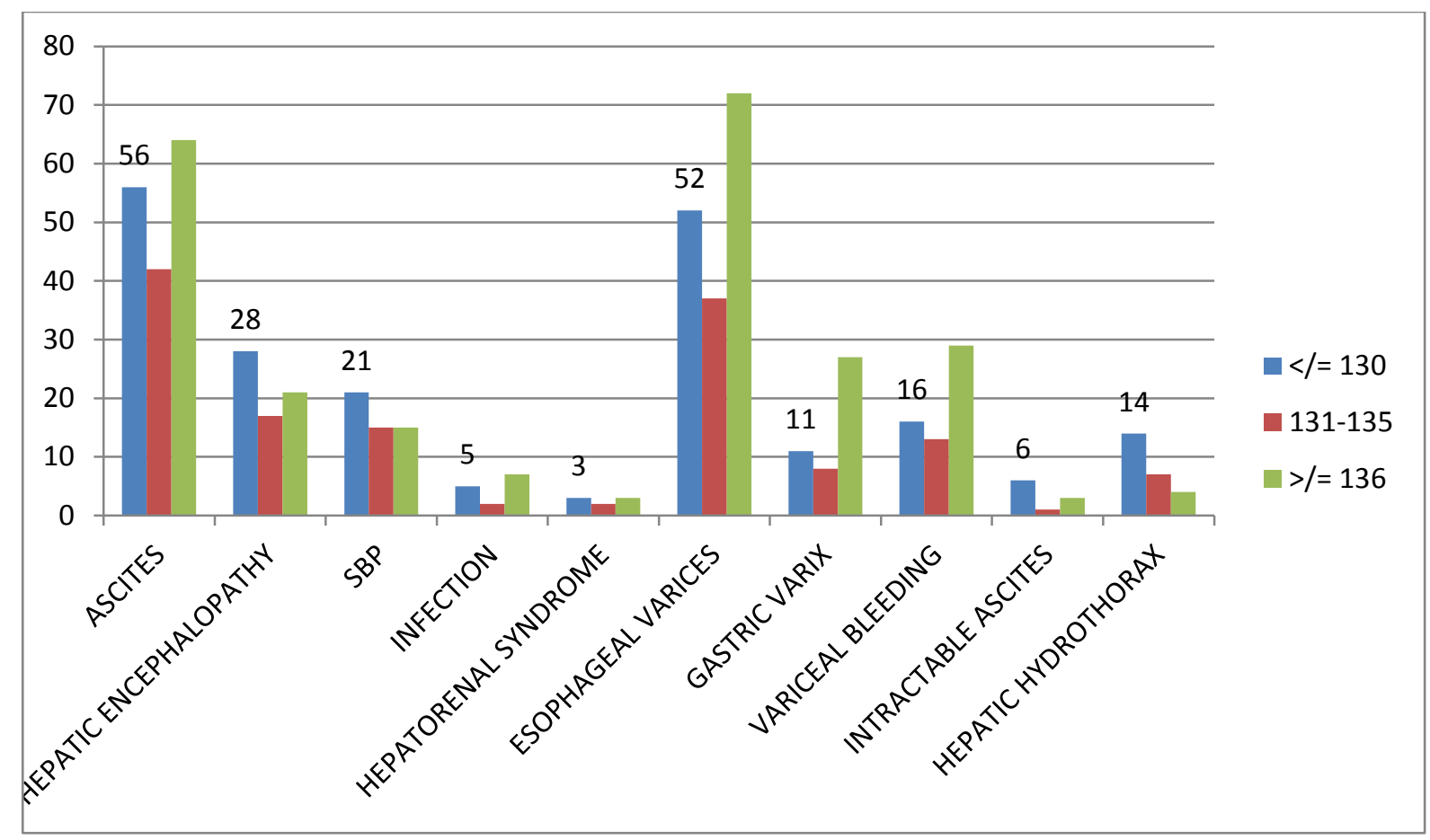

\section{Conclusion:-}

Hyponatremia is a commonly encountered problem in patients with end stage liver disease .Low serum sodium is a poor prognostic indicator in both the pre \&post transplant patient population .It is associated with increased risk of early mortality \& complications including infection, hepatorenal syndrome, \&encephalopathy. So patients with reduced serum sodium levels should be considered high risk population due to increased frequency of complications $\&$ mortality.

\section{References:-}

1. Angeli P, Wong F, Watson H, Gines P. Hyponatremia in cirrhosis: results of a patient population survey. Hepatology 2006;44:15351542.

2. Heuman DM, Abou-Assi SG, Habib A, et al. Persistent ascites and low serum sodium identify patients with cirrhosis and low MELD scores who are at high risk for early death. Hepatology 2004; 40:802-810.

3. Fernandez-Esparrach G, Sanchez-Fueyo A,Gines P, et al. A prognostic model for predicting survival in cirrhosis with ascites. J Hepatol 2001;34:46-52.

4. Ripoll C, Banares R, Rincon D, et al. Influence of hepatic venous pressure gradient on the prediction of survival of patients with cirrhosis in the MELD Era. Hepatology 2005;42:793-801.

5. Arroyo V, Rodes J, Gutierrez-Lizarraga MA, Revert L. Prognostic value of spontaneous hyponatremia in cirrhosis with ascites. Am J Dig Dis 1976;21:249-256.

6. Llach J, Gines P, Arroyo V, et al. Prognostic value of arterial pressure, endogenous vasoactive systems, and renal function in cirrhotic patients admitted to the hospital for the treatment of ascites. Gastroenterology 1988;94:482-487.

7. Gines P, Quintero E, Arroyo V, et al. Compensated cirrhosis: natural history and prognostic factors. Hepatology 1987;7:122128.

8. Cosby RL, Yee B, Schrier RW. New classification with prognostic value in cirrhotic patients. Miner Electrolyte Metab 1989;15:261266.

9. Jong HoonKim,June sung lee,Won Ki Bae, Nam Hoon Kim, Kyung -Ah Kim and Young -Soo Moon . 10.3904/kjim.2009.24.2.106

10. Harrison's principles of Internal medicine: 19 thedition :page no 2058. 